А.В. МАКАРИНСЬКА, канд. техн. наук, доцент, І.С. ЧЕРНЕГА, канд. техн. наук, доцент,

А.А. ОГАНЕСЯН, магістр

Одеська національна академія харчових технологій, м. Одеса

\title{
ПЕРЕВАГИ ВИКОРИСТАННЯ БІЛКОВИХ РОСЛИННИХ КОНЦЕНТРАТІВ ПРИ ВИРОБНИЦТВІ КОМБІКОРМОВОЇ ПРОДУКЦЇ̈
}

\begin{abstract}
Анотація
У тваринництві, головним є організація раціональної годівлі. Хороша кормова база є запорукою повноцінного розвитку иієї галузі. Тому, велике значення відводиться виробництву комбікормів, які повинні повністю задовольняти організм тварин в усіх поживних і біологічно активних речовинах, так як незначний їх дефіцит затримує ріст тварин $і$ не дозволяє 8 подальшому використовувати їх продуктивний потенціал на необхідному рівні.

Сучасні породи і кроси сільськогосподарських тварин особливо вимогливі до поживності рачіону $і$ якості білка в ньому, що відчутно позначається на вартості корму. Додаткові джерела протеїну, отримані шляхом промислової переробки i синтезу сировини рослинного і тваринного походження, дозволяють замінити частину дорогих рослинних $і$ тваринних інгредієнтів в кормах.

Основним джерелом білка в раціоні продуктивних тварин є зернобобові культури та корми тваринного походження. Проте, використання зернобобових при виробництві комбікормів обмежується через високий вміст антипоживних речовин. А використання кормів тваринного походження - забороною на їх використання в країнах ЄС та їх сильними коливаннями за якістю.

Використання білкових рослинних концентратів при виробництві комбікормової продукцї̈ дозволить вирішити перелічені проблеми, оскільки характеризуються високим вмістом протеїну та невеликою вартістю.

Для визначення доцільності використання білкових рослинних концентратів в якості компонента комбікорму, було досліджено їх класифікації та методи отримання. В статті наведена приниипова схема виробництва соєвого концентрату та аналіз хімічного складу і поживності деяких соєвих продуктів.

Білковий рослинний концентрат в різних співвідношеннях може використовуватися для відгодівлі всіх груп тварин, через хорошу засвоюваність сприяє підвищенню продуктивності, знижує ризик кишкових хвороб і характеризується високою біологічною иінністю.
\end{abstract}

Ключові слова: білкові рослинні концентрати, класифікація, методи отримання, соєвий концентрат, комбікорм.

Вступ

Потреба в повнораціонного білку зростає в зв'язку 3 прискореним розвитком промисловості, виробництва бройлерів, м'ясної і беконної свинини, а також інтенсивної відгодівлі молодняку великої рогатої худоби.

Для забезпечення раціонів протеїном існує декілька шляхів, зокрема необхідно збільшити валове виробництво рослинного протеїну, використання замінників білкових кормів та розширити виробництво білкових ізолятів тощо $[1,2]$.

Виключення кормів тваринного походження може бути обумовлено:

$>$ забороною на використання кормів тваринного походження в країнах СС;

$>$ їх сильними коливаннями за якістю;

$>$ небезпекою перенесення сальмонели;

виробників;

частою зміною постачальників

$>$ ризикованими способами консервування;

$>$ можливістю використання місцевих ресурсів при вирощуванні рослинних компонентів білкової групи [3].

У зв'язку з цим метою роботи є: дослідження доцільності використання білкових рослинних концентратів при виробництві комбікормової продукції.

Білкові концентрати - продукти, отримані 3 природних продуктів тваринного або рослинного походження. Вони призначені для збагачення продуктів білком, надають їм велику поживну цінність, a найголовніше замінюють дорогі білки на більш дешеві $[4,6]$.

Переваги використання білкових концентратів:

$>$ висока перетравність;

$>$ висока біологічна цінність;

$>$ покращують споживання корму;

> зміцнюють здоров'я кишківника;

$>$ знижують ризику діареї;

> сприяють підвищенню продуктивності;

$>$ мають хорошу сипкість;

$>$ підвищують міцність гранули;

$>$ мають приємний запах.

В якості сировини для їх отримання можуть використовувати зернові культури (горох, кукурудза, соя, і т.д.), дріжджі, відходи харчової промисловості, їх гідролізат i концентрати, отримані в результаті ферментативної обробки [5].

Білкові концентрати класифікують за походженням на: яєчні, молочні (казеїнові i сироваткові), соєві, рисові, горохові, кукурудзяні, дріжджові і т.д.

Залежно від ступеня очищення білка, його концентрації після ферментної обробки отримують різні види білкових продуктів (гідролізат, концентрат, ізолят). А також білкові концентрати можна класифікувати за фізиними властивостями на рідкі (гелеобразні i пастообразні) i сухі. На рис. 1 представлена класифікація білкових концентратів.

Існуючі в даний час методи отримання білкових продуктів і ізолятів можна класифікувати на: механічні (пресування, віджимання); хімічні, біохіміч- 


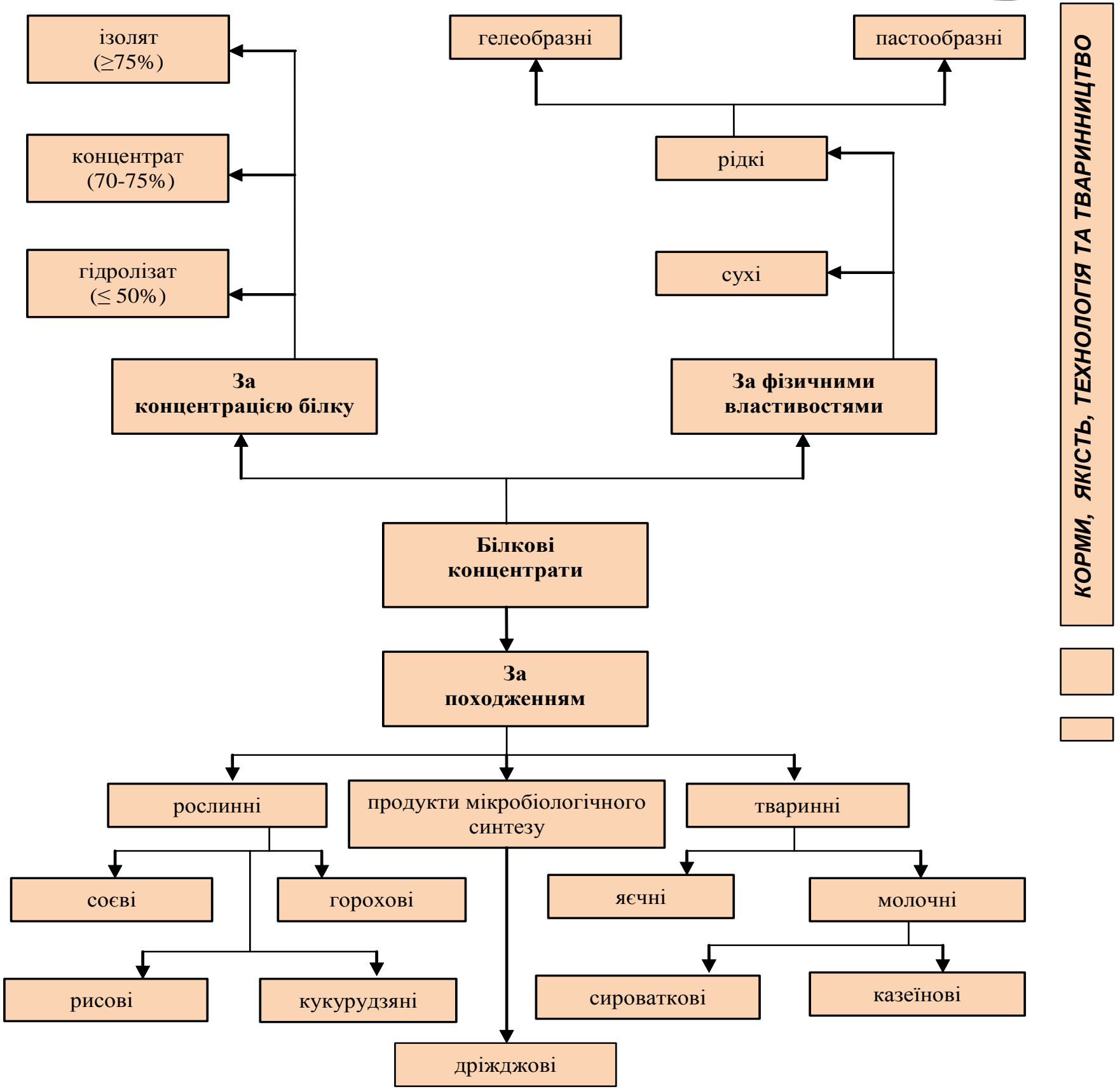

Рис. 1 - Класифікація білкових концентратів.

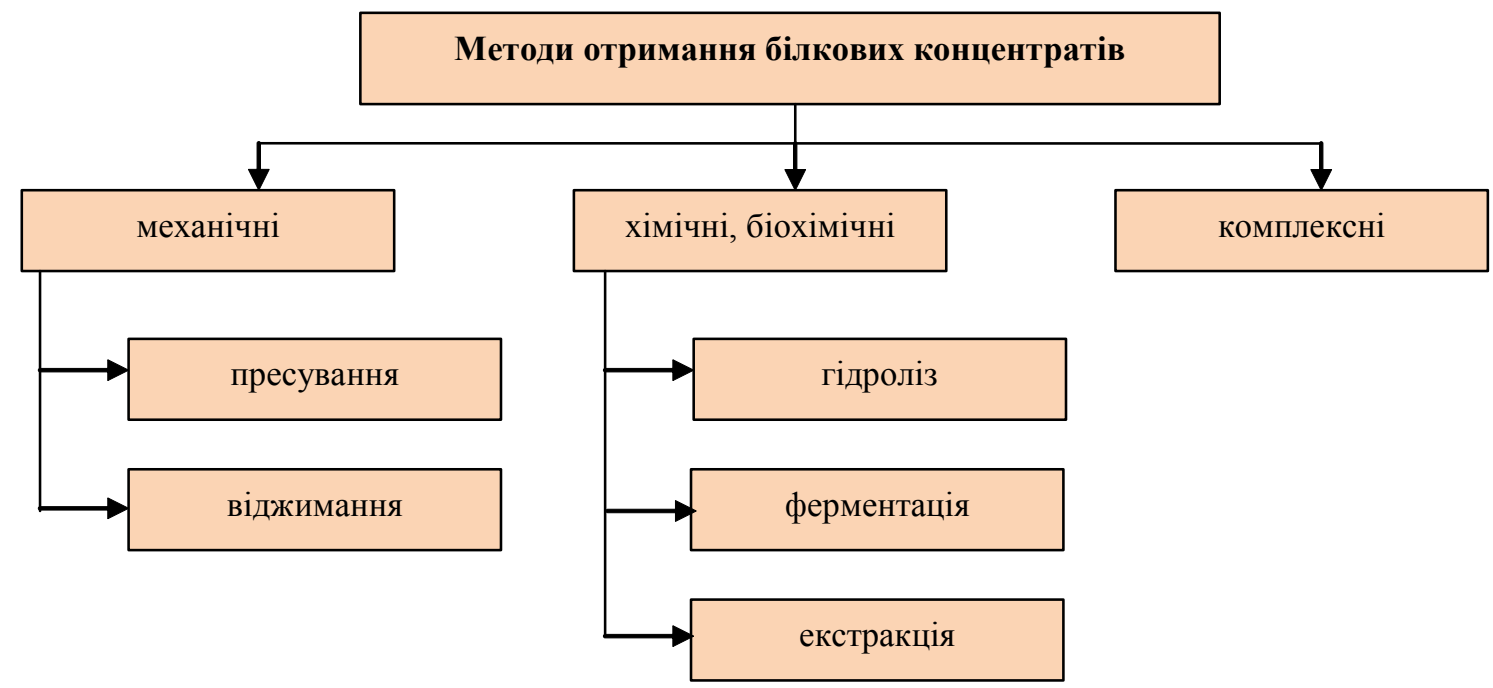

Рис. 2 - Класифікація методів отримання білкових концентратів. 


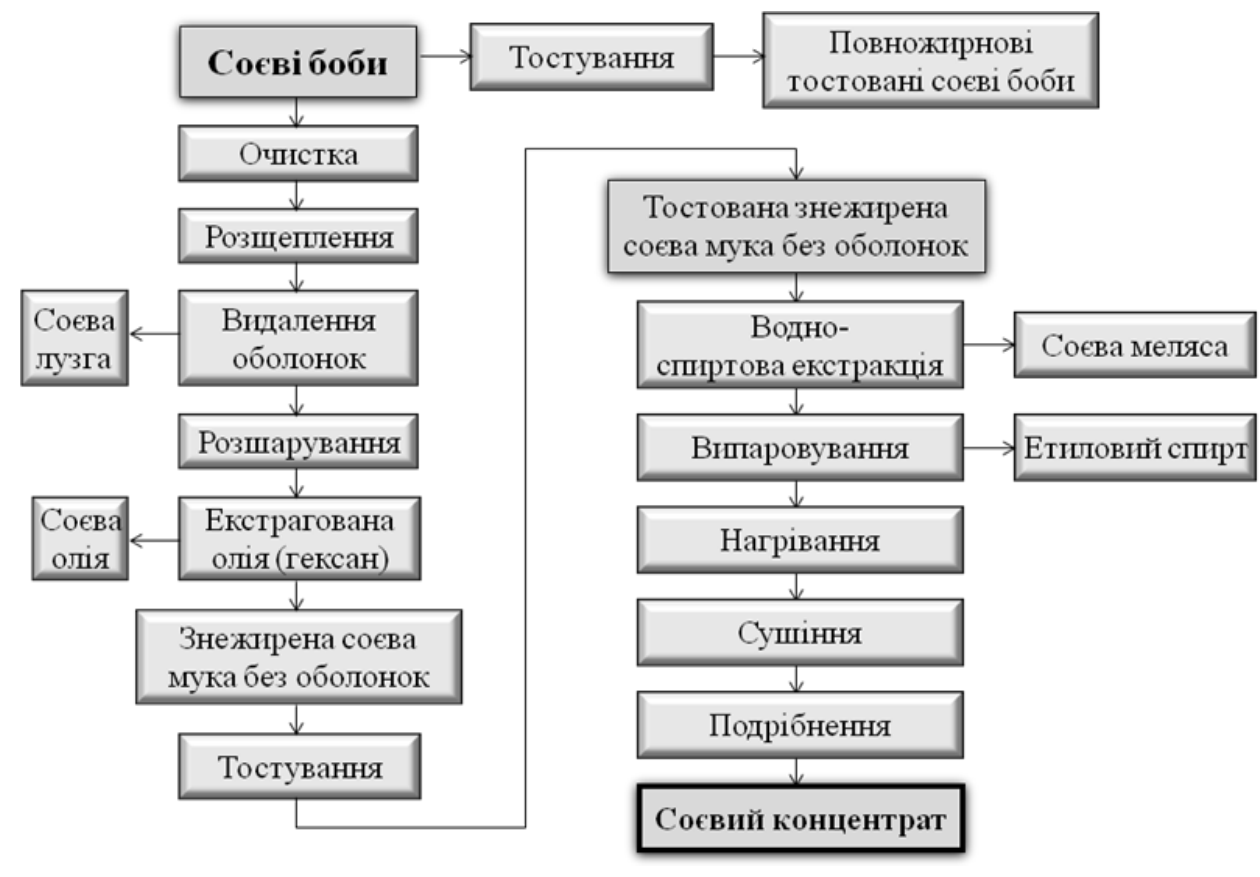

Рис. 3 - Принципова схема виробництва соєвого концентрату цьому, основні фракції білків представлені в високодоступній формі.

Переваги технології отримання соєвого білкового концентрату:

$>$ витяг розчинних вуглеводів;

$>$ висока перетрав-

ність білка;

$>$ якісно хороший амінокислотний профіль;

$>$ зниження вмісту антипоживних речовин;

$>$ низький вміст антигенів;

поліпшені санітарно-гігієнічні характеристики;

$>$ тривалий термін зберігання.

Концентрат соєвий білковий призначений для використання в кормових ні (екстракція, ферментація, гідроліз); комплексні (рис. $2)$.

До специфічних компонентів предстартерів і стартерів традиційно відноситься якісне рибне борошно. Її вводять в зазначені комбікорми як ключовий компонент повноцінного максимально перетравного білка в кількості 5..8 \% по масі. Однак якісну рибну муку на ринку СНД і навіть на світовому ринку знайти сьогодні дуже важко, і до того ж воно дороге. Саме тому пріоритети ключового компонента предстартера і стартера в останні роки перейшли від рибного борошна до так званих білкових концентратів високоякісного рослинного білка. Головними фігурантами ринку таких білкових добавок в світі стали концентрати соєвого білка і їх суміші з іншими повноцінними білками (наприклад, 3 дріжджовим). Рівень протеїну в таких продуктах зростає до відмітки $55 \%$ і більше, з яких на білок припадає не менше $50 \%$ [5-7].

На рис. 3. представлена принципова схема виробництва соєвого концентрату.

Переваги технології отримання концентрату соєвого білкового:

Соєвий білковий концентрат - це очищений білковий продукт, що містить до 65 \% сирого протеїну.

Соєвий протеїновий концентрат виробляється зі шроту соєвого кормового тостованого або шроту соєвого харчового (білого пелюстка), звільненого від розчинних цукрів в процесі спиртової екстракції. При

цілях шляхом безпосереднього введення в раціони тварин або для виробництва комбікормової продукції. Соєвий білковий концентрат придатний для введення в корми всім видам тварин, птиці та риби [5].

Соєві протеїнові концентрати - це продукти глибокої переробки сої. У порівнянні з соєвим шротом, харчова цінність соєвих концентратів набагато більше, а рівень олігосахаридів і антигенних факторів дуже низький

Найбільш важливі продукти переробки сої: повножирова соя, соєвий шрот, ферментована соя, Гамлет протеїн фірми «Авістарт» і соєвий концентрат. I як бачимо найбільший відсоток білка в соєвому концентраті (таблиця 1) [8-12].

Таблиця 1 - Вміст білка у соєвих продуктах

\begin{tabular}{||l||c|}
\hline \hline Продукти & Білок, $\%$ \\
\hline \hline Повножирова соя & $36-38$ \\
\hline \hline Соєвий шрот & $47-48$ \\
\hline \hline Ферментована соя & $50-53$ \\
\hline \hline Гамлет протеїн & $55-57,5$ \\
\hline \hline Соєвий концентрат & $65-68$ \\
\hline
\end{tabular}

У таблиці 2 наведені порівняльні дані хімічного складу і поживності деяких соєпродуктів і концентратів, отриманих з них.

Таблиця 2 - Аналіз хімічного складу і поживності деяких соєвих продуктів

\begin{tabular}{|c|c|c|c|c|c|}
\hline Продукти & Жир, \% & Вуглеводи, \% & Клітковина, \% & Білок, \% & Зола, \% \\
\hline Боби сої сирі & 21.0 & 27,0 & 6,0 & 40,5 & 5,5 \\
\hline Повножирова соя без плівок & 21,5 & 28,5 & 3,0 & 42,0 & 5,0 \\
\hline Соєвий шрот & 1,5 & 35,5 & 4,0 & 53,0 & 6,0 \\
\hline Ферментована соя & 2,5 & 29,5 & 4,5 & 56,0 & 7,5 \\
\hline Гамлет протеїн & 3,0 & 25,0 & 3,5 & 61,0 & 7,5 \\
\hline Соєвий концентрат & 0,5 & 18,5 & 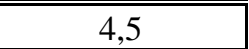 & 70,0 & 6,5 \\
\hline
\end{tabular}


Таблиця 3 - Аналіз амінокислотного складу і поживності деяких сосвих продуктів

\begin{tabular}{|c|c|c|c|c|c|c|c|c|}
\hline \multirow{2}{*}{$\begin{array}{l}\text { Аміно- } \\
\text { кислота }\end{array}$} & \multicolumn{2}{|c|}{ Повножирова соя } & \multicolumn{2}{|c|}{ Сосвий шрот } & \multicolumn{2}{|c|}{ Сосвий концентрат } & \multicolumn{2}{|c|}{ Гамлет протеїн } \\
\hline & загальні & $\begin{array}{l}\text { засво- } \\
\text { ювані }\end{array}$ & загальні & $\begin{array}{l}\text { засво- } \\
\text { ювані }\end{array}$ & загальні & $\begin{array}{l}\text { засво- } \\
\text { ювані }\end{array}$ & загальні & $\begin{array}{l}\text { засво- } \\
\text { ювані }\end{array}$ \\
\hline Лізин & 22,0 & 19,8 & 25,8 & 22,4 & 38,0 & 32,5 & 32,2 & 31,0 \\
\hline Метіонін & 4,8 & 4,0 & 5,7 & 4,9 & 9,1 & 7,3 & 7,5 & 7,5 \\
\hline Цистин & 5,9 & 4,8 & 6,0 & 5,0 & 7,9 & 5,4 & 7,8 & 7,3 \\
\hline Треонін & 14,8 & 12,0 & 16,0 & 13,4 & 24,0 & 20,9 & 21,7 & 21,7 \\
\hline Триптофан & 4,0 & 3,3 & 5,6 & 4,6 & 8,3 & 7,1 & 7,5 & 7,5 \\
\hline Лейцин & 28,0 & 24,1 & 26,0 & 23,1 & 46,7 & 40,2 & 41,4 & 41,0 \\
\hline І Ізолейцин & 15,5 & 13,5 & 17,8 & 15,8 & 29,0 & 25,1 & 25,6 & 25,6 \\
\hline Валін & 17,6 & 14,8 & 18,8 & 16,5 & 27,5 & 24,3 & 26,7 & 24,3 \\
\hline Гістидин & 10,3 & 9,1 & 10,8 & 9,9 & 15,5 & 12,9 & 14,2 & 14,2 \\
\hline Фенілаланін & 18,3 & 15,4 & 20,4 & 18,2 & 31,8 & 27,1 & 27,5 & 27,5 \\
\hline Аргінін & 28,4 & 21,6 & 29,2 & 23,9 & 46,0 & 38,1 & 38,9 & 37,3 \\
\hline Гліцин & 15,7 & 12,5 & 17,4 & 16,3 & 24,2 & 20,0 & 23,7 & 23,7 \\
\hline
\end{tabular}

Згідно даних табл. 3, соєві концентрати випереджають шрот сої і повножирову сою за рівнем сирого протеїну як мінімум на $20 \%$. Соя спрощеної обробки явно поступається концентратам за ступенем перетравності вуглеводів і серйозно випереджає їх по накопиченню сирої клітковини. Ось чому традиційні соєві продукти характеризуються зниженою перетравністю сухої речовини (менше $85 \%$ ) проти понад $90 \%$ у соєвих концентратах. Рівень протеїну в соєвому концентраті найвищий [8-12].

Якість протеїну в першу чергу залежить від збалансованості по амінокислотам. У таблиці 3 наведені порівняльні дані амінокислотного складу і поживності деяких соєвих продуктів і концентратів, отриманих з них [3].

Дані таблиці 3 свідчать, що концентровані соєві продукти на відміну від повножирової сої і шроту характеризуються істотно вищим накопиченням незамінних амінокислот в складі білка. При цьому частка їх засвоювання частини у стандартних соєвих продуктів нижче більш ніж на $10 \%$ в порівнянні 3 концентратами сої.

Третім найважливішим фактором порівняння соєвих продуктів різного ступеня концентрування амінокислот $є$ наявність в них залишкових кількостей антипоживних речовин по більш широкому колу показників, ніж при звичайній стандартній оцінці.

Соєвий протеїновий концентрат пропонується як ефективна альтернатива високоякісним білків тваринного походження, а саме - замінника незбираного молока i рибного борошна в годівлі поросят, курчат-бройлерів. У предстартерних і стартерних кормах для свиней може замінювати сухе знежирене молоко, молочну сироватку i рибне борошно, при цьому за харчовою цінністю не поступається вище сказаним інгредієнтів.

Крім цього, амінокислотний склад соєвого протеїнового концентрату ідеально відповідає потребам молодих тварин. Він містить високий рівень органічних амінокислот - лізину, метіоніну, треоніну, триптофану [8-12].

Система травлення молодих поросят недос-

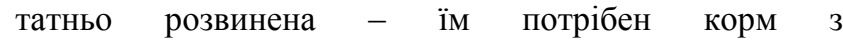
високоперетравним білком. Тому в предстартерних і стартерних кормах для поросят використовуються високоякісні легкозасвоювані продукти, наприклад білки молока або плазми. Однак використання цих джерел протеїну значно підвищує вартість кормів [12$14]$.

Використання соєвого протеїнового концентрату в якості альтернативи дорогим джерел протеїну - замінника незбираного молока і рибному борошні, сприяе підтримці швидкості росту і зменшення вартості кормів.

Засвоюваність амінокислот в соєвому протеїновому концентраті більше, ніж в звичайних соєвих продуктах.

Якісні показники рибного борошна і соєвого концентрату щодо сходяться, розбіжність невелика, але при цьому соєвий концентрат на порядок дешевше.

Області застосування i норми введення соєвого білкового концентрату $[5,6]$ :

$>$ корми для сільськогосподарських тварин та птиці $-5 \ldots 20 \%$;

$>\quad$ корми для поросят $-5 \ldots 20 \%$;

$>\quad$ корми для аквакультури, в залежності від виду риб рівень введення - від 50 до $100 \%$ заміни рибного борошна;

$>$ замінник молока для телят;

$>\quad$ корми для домашніх тварин $-5 \ldots 10 \%$.

Соєві концентрати $є$ насамперед цікаві тим, що $\epsilon$ кращими карбогидратами для кишківника, тобто їх використання забезпечує збалансоване здорове травлення для поросят, птиці та домашніх тварин. Нові методи виготовлення соєвого концентрату сприяють ефективності поглинання поживних речовин уже в тонкому кишківнику, їх засвоюваності, скорочення субстратів для потенційних шкідливих бактерій i збільшення ефективності субстратів позитивних бактерій, тобто продукт виконує функцію профілактичного лікарського засобу.

Соєвий білковий концентрат в різних співвідношеннях може використовуватися для відгодівлі всіх груп тварин, через хорошу 
засвоюваність сприяє природному збільшенню ваги, знижує ризик кишкових хвороб і усуває бактерії, які сприяють підвищенню рівня аміаку в крові. Продукт також діє як пробіотик і розщеплює полісахариди.

Соєвий білковий концентрат $є$ органічним продуктом 3 високим вмістом фосфору зі здатністю поєднувати життєво важливі мінерали, такі як кальцій, магній, залізо, цинк, поєднуються з білками і сприяють поліпшенню травлення [5-7].

\section{Висновки: \\ $>$ досліджено переваги використання}

білкових рослинних концентратів в кормовиробництві;
$>$ проаналізовано методи

отримання

білкових концентратів;

концентратів;
дано
класифікацію
білкових

$>$ представлена принципова виробництва білкового соєвого концентрату;

$>$ досліджено вміст білка у соєвих продуктах;

$>$ проведено аналіз хімічного складу i поживності деяких соєвих продуктів;

$>\quad$ проведено аналіз амінокислотного складу і поживності деяких соєвих продуктів.

\title{
ЛITЕРАТУРА
}

1. Макаринська А.В. Стан виробництва та забезпечення населення України продуктами тваринництва / А.В. Макаринська // Зернові продукти і комбікорми. - 2010. - №2. - с. 37-39.

2. Нечитайло Ю.Я. Разработка технологии производства кормовой добавки из побочных продуктов переработки гидробионтов [Электронный ресурс] / Ю.Я. Нечитайло // Режим доступа: http://extrutec.ck.ua/lectures/2.html

3. Стратегия кормления свиней без использования кормов животного происхождения [Электронный ресурс] - Режим доступа: https://soft-agro.com/svini/strategiya-kormleniya-svinej-bez-ispolzovaniya-kormov-zhivotnogo-proisxozhdeniya.html

4. Пономарев В.В. Белковый кониентрат и способ его производства [Электронный ресурс] / В.В. Пономарев, Т. М. Бикбов - Режим достуnа: https://patents.google.com/patent/WO2010123396A1/ru

5. Концентрат соевый белковый (кормовой) [Электронный ресурс] - Режим доступа: http://www.sodrugestvo.ru/our_business/global_trade/own_production/spc/

6. Белковые концентраты [Электронный ресурс] - Режим доступа: http://food-chem.ru/lektsii-po-khimii-belkov/belkovyekontsentraty-teksturirovannye-belkovye-produkty

7. Белок растительного происхождения [Электронный ресурс] - Режим достуnа: https://agrosmak.ua/belok-rastitelnogoproischogdenial

8. Jackson M. Improving soya utilization in monogastrics: maize-soya diets with B-mannanase [Text] / M. Jackson // Feed international. 2001. - V.22 - №12. - P. 22-26.

9. Турін Є. Соя в годівлі птиці / С. Турін // Тваринництвво України. - 2008. - №2. - С. 31-32.

10. Бортников С. Эффективность использования полножирной экструдированной сои [Текст] / С. Бортников // Комбикорма. 2005. - №1. - C. 51-52.

11. Специализированный белковый концентрат (Гамлет Протеин) Дания [Электронный ресурс] - Режим доступа: http://www.altua.com/ru/catalog/raw/protein-components/specialized-protein-concentrate.html

12. Подобед Л.И. Гамлет Протеин [Электронный ресурс] / Л.И. Подобед - Режим достуnа: http://podobed.org/gamlet_protein.html

13. Что входит в состав престартеров для поросят [Электронный ресурс] - Pежим доступа: https://softagro.com/svini/sostavlyayushhie-prestarterov-dlya-porosyat.html

14. Ібатулін I.І. Годівля сільськогосподарських тварин / I.І. Ібатулін, Д.О. Мельничук, Г.О. Богданов та ін.: підручник. - Вінниця: Нова книга, 2007. - 616 c.

\section{A.V. MAKARYNSKA, PhD. Sc., Ass. Prof., I.S. CHERNEGA, PhD. Sc., Ass. Prof.,}

A.A. OGANESYAN, master's degree

Odessa National Academy of Food Technologies, Odessa

\section{ADVANTAGES OF VEGETABLE PROTEIN CONCENTRATES IN PRODUCTION ANIMAL FEED}

\begin{abstract}
In animal husbandry, the main thing is the organization of rational feeding. A good feed base is the key to the full development of this industry. Therefore, great importance is given to the production of feed, which must fully satisfy the body of animals in all nutrients and biologically active substances, since their insignificant shortage inhibits the growth of animals and prevents them from further using their productive potential at the required level.

Modern breeds and crosses of farm animals are especially demanding for dietary nutrition and the quality of protein in it, which significantly affects the value of feed. Additional sources of protein, obtained by industrial processing and synthesis of raw materials of plant and animal origin, can replace some of the expensive plant and animal ingredients in feed.

The main source of protein in the diet of productive animals is leguminous crops and animal feed. However, the use of legumes in the production of feed is limited due to the high content of anti-nutrients. And the use of animal feed-a ban on their use in EU countries and their strong fluctuations in quality.

The use of protein plant concentrates in the production of feed products will solve the listed problems, because they are characterized by high protein content and low cost.

In order to determine the feasibility of using proteinaceous plant concentrates as a component of feed, their classifications and methods of obtaining were investigated. Also in the article the basic scheme of production of soy concentrate and the analysis of the chemical composition and nutrition of some soy products are given.

Protein concentrate in different ratios can be used for fattening all groups of animals, because of good digestibility contributes to increased productivity, reduces the risk of intestinal diseases and is characterized by high biological value.

Key words: protein plant concentrates, classification, production methods, soy concentrate, animal feed.
\end{abstract}




\title{
REFERENCES
}

1. Makarinska A.V. State of production and provision of Ukrainian population products of livestock / A.V. Makarinska // Cereal products and feed. - 2010. - No. 2. - with. 37-39

2. Nechitaylo Y.Y. Development of technology for the production of feed additives from by-products of hydrobionts processing [Electronic resource] / Y.Y. Nechitaylo // Access mode: http://extrutec.ck.ua/lectures/2.html

3. Strategy of feeding pigs without the use of animal feed [Electronic resource] - Access mode: https://soft-agro.com/svini/strategiya-kormleniyasvinej-bez-ispolzovaniya-kormov-zhivotnogo-proisxozhdeniya.html

4. Ponomarev V.V. Protein concentrate and the method of its production [Electron resource] / V.V. Ponomarev, T. M. Bikbov - Access mode: https://patents.google.com/patent/WO2010123396A1/ru

5. Concentrate of soy protein (fodder) [Electronic resource] - Access mode: http://www.sodrugestvo.ru/our_business/global_trade/own_production/spc/

6. Protein concentrates [Electronic resource] - Access mode: http:/lfood-chem.ru/lektsii-po-khimii-belkov/belkovye-kontsentratyteksturirovannye-belkovye-produkty

7. Protein of vegetable origin [Electronic resource] - Access mode: https://agrosmak.ua/belok-rastitelnogo-proischogdenia/

8. Jackson M. Improving soya utilization in monogastrics: bread-soya diets with B-mannanase [Text] / M. Jackson // Feed international. - 2001. V.22 - No. 12. - P. 22-26.

9. $\quad$ Turin E. Soya in feeding birds / E. Turin // Livestock of Ukraine. - 2008. - No. 2. - P. 31-32.

10. Bortnikov S. Efficiency of using full-fat extruded soybeans [Text] /S. Bortnikov // Combined feed. - 2005. - №1. - P. 51-52.

11. Specialty Protein Concentrate (Hamlet Protein) Denmark [Electronic resource] - Access mode: : http://www.altua.com/ru/catalog/raw/protein-components/specialized-protein-concentrate.html

12. Podobed L.I. Hamlet Protein [Electronic resource] / L.I. Podobed // Access mode: http://podobed.org/gamlet_protein.html

13. What is a part of the predsters for pigs [Electronic resource] - Access mode: https://soft-agro.com/svini/sostavlyayushhie-prestarterov-dlyaporosyat.html

14. Ibatulin II Feeding farm animals / I.I. Ibatulin, D.O. Melnichuk, G.O. Bogdanov, etc.: a textbook. - Vinnitsa: New Book, 2007. - 616 p. Надійила 08.06.2018. До друку 26.06.2018. Рецензія 14.06.2018

T.V. SAKHNO, chem. sci. dr., professor, P.V. PISARENKO, agr. sci. dr., professor,

I.V. KOROTKOVA, PhD in Chemistry, Poltava State Agrarian Academy,

O. M. OMELIAN, PhD in Phis.-math., Poltava National Technical University Yu. Kondratyuk',

N. N. BARASHKOV, chem. sci. dr., professor, Micro-Tracers Inc., San-Francisco, USA

\section{THE APPLICATION OF STATISTICAL METHODS OF QUALITY MANAGEMENT BY GMP+ STANDARDS USING FERROMAGNETIC MICROTRACERS}

\begin{abstract}
The GMP +FSA Feed Certification scheme is considered and analyzed which was developed in 1992 by the Dutch feed industry in response to various incidents involving contamination in feed materials. Currently it is an international scheme that is managed by GMP+ International in collaboration with stakeholders from numerous European countries. One of the most important and responsible steps in the feed production is mixing - creating a completely homogeneous mixture. In this paper, a statistical quality assessment of mixing of multicomponent feeds using the distribution of added particles - microtracers was performed. The testing procedure of the homogeneity of feeds and premixes using microtracers is presented in the Standard GMP+ BA2 "Control of residues". The ferromagnetic variety of microtracers manufactured by American Company Micro-Tracers, Inc (San Francisco, California) are elementary iron particles or particles of stainless steel which are coated with a FD\&C dye of different colors. The most common microtracers are Microtracer F that consists near 25000 of iron particles with a size distribution of 150 - $300 \mu$ m. These microtracers are used in the feed industry to ensure the quality of mixing feeds for animals and poultry during the last $20-30$ years. The additional areas of use of microtracers include the marking of vitamins, mineral additive or medicament which introduced into premixes, which allows to mark the presence of the premix in the finished feeds. In quantitative analysis, Microtracers ${ }^{T M}$ can be used not only to document efficacy of mixing, but also to assess the adequacy of batch to batch "cleanout" of mixers and other feed manufacturing equipment.

In the present article the analytical results of evaluation of the mixer performance are interpreted in the terms of a Poisson statistics and chi-squared distribution. The value of probability by Poisson ( $p$ ) was chosen as criteria for evaluation of homogeneity. Treating a series of counts as a Poisson distribution, the mix is judged complete if $p>5 \%$ and judged incomplete if $p<1 \%$. The mix is judged "probably incomplete" (marginal) if the probability value is in the range of $1 \%<p<5 \%$.
\end{abstract}

Key words: feed certification, ferromagnetic microtracers, Poisson distribution, chi-squared.

\section{Introduction}

The signing of the Agreement on the Association of Ukraine with the EU allowed domestic producers of agricultural products to enter the promising European market. As it is known, this market is characterized by a high level of competition, and in order to occupy a worthy place in the European market a high level of quality and safety of the products is necessary. One of the certification systems that ensure the production of products whish are corresponding the European quality and safety standards is the GMP+ system. 